\title{
Dangerous Voices: On Written and Spoken Discourse in Plato's Protagoras
}

\author{
Olof Pettersson
}

Plato's Protagoras contains, among other things, ${ }^{1}$ three short but puzzling remarks on the media of philosophy. First, at 328e5-329b1, Plato makes Socrates worry that long speeches, just like books, are deceptive, because they operate in a discursive mode void of questions and answers. Second, at 347c3-348a2, Socrates argues that discussion of poetry is a presumptuous affair, because, the poems' message, just like the message of any written text, cannot be properly examined if the author is not present. Third, at 360e6-361d6, it becomes clear that even if the conversation between Socrates and Protagoras was conducted by means of short questions and answers, this spoken mode of discourse is problematic too, because it ended up distracting the inquiry from its proper course. As this paper ${ }^{2}$ sets out to argue, Plato does not only make Socrates articulate these worries to exhibit the hazards of discursive commodification. In line with Socrates' warning to the young Hippocrates of the dangers of sophistic rhetoric, and the sophists' practice of trading in teachings, they are also meant to problematize the thin line between philosophical and sophistical practice. By examining these worries in the light of how the three relevant modes of discourse are exemplified in the dialogue, this paper aims to isolate and clarify the reasons behind them in terms of deceit, presumptuousness and dis-

\footnotetext{
${ }^{1}$ Nowadays, is often thought that the Protagoras' should be understood in the light of its "negative dialectic" and Socrates' attempt to refute whatever Protagoras is taken to represent. So, e.g. Long (2005), McCoy (2008), Russel (2000), and Hemmenway (1996). Cf. also Klosko (1980), Zeyl (1980), and Grube (1933). This line of thought stands in contrast to the view that the Protagoras is primarily designed to give voice to a set of more positive ideas. The three usual suspects are: (1) the Unity of the Virtues, e.g. Vlastos (1972); Woodruff (1976), Kraut (1984), Penner (1973), Brickhouse and Smith (1997), and O'Brien (2003), (2) the Denial of Akrasia, e.g. Brickhouse and Smith (2007) and Devereux (1995), and (3) some version of Hedonism, e.g. Cronquist (1975) and Hackforth (1928). For a survey, see Lavery (2007).

${ }^{2}$ I am grateful to Marina McCoy for her comments on an early version of this text.

O. Pettersson $(\triangle)$

Department of Philosophy, University of Bergen, Bergen, Norway

e-mail: Olof.Pettersson@ filosofi.uu.se
} 
traction; and to argue that these reasons cast doubts on the common assumption that the dialogue's primary aim is to show how sophistical rhetoric must succumb to Socratic dialectic (e.g. Long 2005, 3; Benitez 1992, 242; Stenzel 1973, 31).

\section{The Nature and Teachability of Virtue}

Although the self-critical vein of these passages has not received much attention in the scholarly literature, ${ }^{3}$ the dialogue's unsettling character is often acknowledged. ${ }^{4}$ Besides the many signs of Protagoras' reluctance to adapt to what seems to be Socrates' preferred mode of discourse, viz. short questions and answers, and Socrates' repeated failure to meet his own standards, ${ }^{5}$ the dialogues' most prominent disappointment is its failure to settle the questions of what virtue is and whether or not it can be taught. ${ }^{6}$ Socrates ends his narration of the encounter with Protagoras by describing what he considers to have been at stake all along:

But no, I [sc. Socrates] said, I am asking all of these things for no other reason than a wish

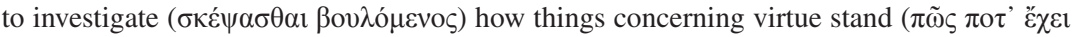

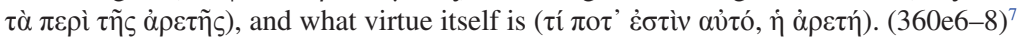

However, this wish has not been satisfied. Should their discourse get a voice ( $\varphi \omega v \eta ́)$ of its own, Socrates says, it would scorn and laugh at them (361a4-5). By means of a subtle distinction between what something is like and what something $i s$, Socrates explains why:

And having already gone through these things, I would now like us to go on to investigate

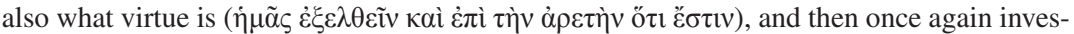

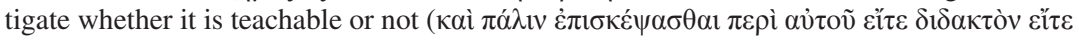

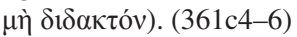

Clearly disappointed, Socrates outlines an alternative and better course of action. He wants to start the examination of virtue anew, but this time with reference to the

\footnotetext{
${ }^{3}$ One important exception is Woolf (1999). Cf. McCoy $(1999,359)$. The reference to written and spoken discourse in the Protagoras is often mentioned in passing in discussions of the Phaedrus, e.g. Mackenzie (1982), Murray (1988), Rowe (1986), Griswold (1986, esp. 222), and Heath (1989).

${ }^{4}$ E.g., Grube (1975, 235). The dialogue's many logical problems are outlined by Taylor (1976). Vlastos is annoyed (1956, xxiv). Trivigno (2013) argues that the dialogue shows the impossible task of interpretation. McCoy $(1999,358)$ claims that Socrates offers a series of "deliberate misreadings". Griswold $(1999,283)$ claims that "one of the striking aspects of the [...] conversation [in the Protagoras] is its failure as a philosophical dialogue." Frede $(1986,736)$ and Schofield (1992, 132) agree.

${ }^{5}$ Cf. 335a4-8 with $319 \mathrm{a} 8-320 \mathrm{c} 1 ; 342 \mathrm{a} 6-347 \mathrm{a} 5 ; \quad 347 \mathrm{~b} 8-348 \mathrm{a} 9 ; \quad 348 \mathrm{c} 5-349 \mathrm{~d} 1 ; 352 \mathrm{a} 1-\mathrm{c} 7$; 354e 3-356c3; 356c4-e4.

${ }^{6}$ So Griswold (1999, 283 and 288), Politis (2012), and Klosko (1980). See also Benitez (1992) and Frede (1992).

${ }^{7}$ If not otherwise stated, the translations are my own.
} 
question of what virtue $i s .{ }^{8}$ Since both Socrates and Protagoras have said quite a lot about virtue, this call for a renewed examination is telling. The dialogue does not only lack an account of what virtue $i s$. All its talk about the qualities of virtue seems to have been in vain. Why?

Socrates does not elaborate the underlying distinction. But it is in line with what Plato has to say about this elsewhere. ${ }^{9}$ Although Socrates and Protagoras discuss the possible quality of virtue, by considering what virtue can be like (i.e. teachable or not), they have not managed to capture that distinguishing feature that makes virtue into what it is. The problem, however, is not only that their discussion merely lacks vital information on this matter. It has also distracted the search from its proper course. Instead of first examining what virtue is, and in turn continue to ask about its teachability, the discussion started in the middle and put the examination on the wrong track from the beginning. And insofar as the dialogue is read as an explicit account of Socrates' take on virtue, this is clearly problematic.

\section{A Warning}

As recently pointed out, there are however reasons to doubt that the sole aim of the Protagoras is to be an inquiry into what virtue is, and whether or not it can be taught. It has accordingly also been argued reasonable to understand the purpose of the dialogue in a different light. ${ }^{10}$ Read as a preliminary warning of what shall come, Socrates' introductory conversation with the young Hippocrates is telling. Clearly with Hippocrates' naïve trust in Protagoras' skills in mind (e.g. 310d6, 310e6 or

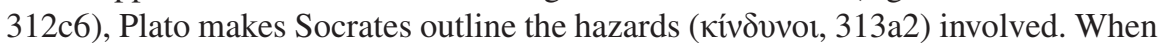
one involves oneself with a sophist, we learn, one risks more than one's physical health. If handled without the proper knowledge, Protagoras' teachings can affect the soul (314b2-3), just like bad food can poison and sicken the body.

Socrates introduces his account of these hazards (313c7-314c2) by likening the

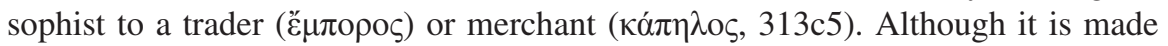
clear that it is hard to pinpoint in what exactly the sophist trades, it has something to do with his voice. The sophist, Hippocrates suggests, is the wisest, or most skilled,

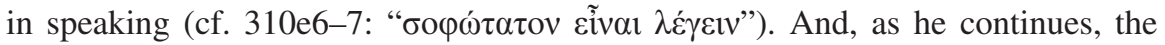
sophist is someone in control of making his clients clever speakers (cf. 312d6-7:

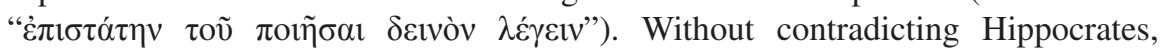
Socrates also goes on to suggests what this may amount to: The sophist trades in

\footnotetext{
${ }^{8}$ So Politis $(2012$, 222). Cf. 360e8-361a3. For discussion of these passages, see Politis (2012, 210ff), Denyer (2012), Robinson (1953a), Benson (2009, esp. 18n53), Prior (1998), and Wolfsdorf (2004).

${ }^{9}$ E.g. Epist. VII. 343b7-c3; Men. 71a1-72d1; Rep. 354a12-c3; Lach. 190b7-c2; Gorg. 448e6-449a4.

${ }^{10}$ E.g. McCoy (2008), Gonzales (2000), Benitez (1992), and Griswold (1999). See also Lavery (2007).
} 
teachings ( $\mu \alpha \theta \eta ́$ $\mu \alpha \tau \alpha, 313 c 7$; Gonzalez 2000, 114 and Griswold 1999, 299n46). In

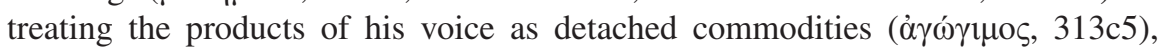
Protagoras considers discursive interaction to be strictly business. Although he uses his voice to defend his teachings in argument - otherwise no one would buy them he does not think that he needs to be personally involved in the practices they describe, or in the views they support. ${ }^{11}$

Although this account of the sophist is articulated before Protagoras himself is introduced, it is confirmed by Protagoras' own words. ${ }^{12}$ Not only is it clear that he considers himself a part of a great tradition of poets and musicians, experts proficient primarily in the arts of the voice. Protagoras also emphasizes the competitive aspect of his trade by associating its traditions with two athletes (Iccus and Herodicus, 316d9-317e1, cf. 332e $2-4,335 \mathrm{a} 4-8$ and 337b1). ${ }^{13}$ In the long speech with which Protagoras introduces his own take on virtue - the so-called Great Speech - the notion of discursive merchandise is also confirmed. Here, Protagoras tells the myth of Prometheus and Epimetheus; in the middle of which he also lays bare his views on the nature and origin of language. The human voice ( $\varphi \omega \vee \eta ์)$ and its ability to articulate words or names (óvó $\mu \alpha \tau \alpha$ ), he says, was given to humanity together with the other arts ( $\tau \dot{\varepsilon} \chi v \alpha 1,322 \mathrm{a} 6)$. In this respect, the products of the human voice are no different than houses, clothes, sandals, beds and food. On Protagoras view, there is supposedly no closer link between the soul and the voice than between the producer and the product. Dissociated from political or social skill

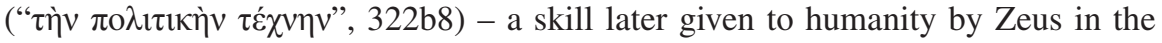
form of justice ( $\delta \dot{\kappa} \kappa \eta)$ and shame ( $\alpha i \delta \omega ́ s, 322 \mathrm{c} 2$ ) - language and discursive interaction is considered to be a competitive enterprise alien to the bonds that unite people

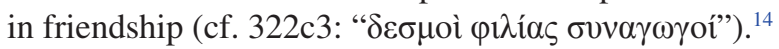

\footnotetext{
${ }^{11}$ So Griswold (1999, 292f.): "[Protagoras' enchanting voice] is a voice that lets Protagoras make himself public but not accountable to others [...] The externality to self of sophist discourse is implicit in their commodification. [Protagoras] lacks a real interest in his students considered as individuals. $[\mathrm{H}] \mathrm{e}$ does not really care about them in a way that would foster their growth as selfcritical and independent thinkers".

${ }^{12}$ I am here only discussing some aspects of the way Protagoras is represented in Plato's dialogue. For a discussion of the historical person, see Notomi (2013) and Woodruff (2013).

${ }^{13}$ So Schofield (1992, 129f.). On Orpheus (poet), Musaeus (poet and mystic) and Herodicus (athlete and sports physician), see Sauppe (1889). On Iccus (athlete and dietologist), see Adam (1893). On Agathocles and Pythocleides (musicians), see Smith (1873, s.v. Pythocleides) and Sauppe (1889).

${ }^{14}$ Cf. 322b5. See also McCoy $(2008,63)$. On Protagoras' theory of language, see Rademaker (2013).
} 


\section{Discursive Hazards}

Although it may seem to be beyond doubt that Socrates' introductory account of Protagoras' practice is designed to prepare Hippocrates for the dangers involved in interacting with a sophist, it tells us very little about what results this may have in actual practice. Further down the line, however, there are three passages that spell out the problems in some more detail.

The first passage includes a critique of Protagoras' discursive proficiency. Having just been given a brilliant example of Protagoras' art, in the form of his long speech on virtue, Plato makes Socrates expresses an important worry.

Should someone consult the public speakers regarding this matter, he would probably hear something similar from Pericles or from some other able speaker. But if he should ask them something more, they themselves, just like books, have nothing either to answer or to ask. For, if someone poses even some small question about what they have said, they go on unless someone interrupts, just like the sound from a copper kettle. And rhetors, in this way, when asked small questions, extend the speech at length. (328e5-329b1, italics added)

On the face of it, the target is Protagoras' speech. But, in consequence of Socrates' peculiar way of phrasing the matter, the critique extends beyond its the boundaries. In principle, it applies to any mode of discourse similar to what may be communicated in the form of written text. ${ }^{15}$ Suggestive, perhaps, of the conceit of Plato's fiction, Socrates does not comment on this (so, e.g., Woolf 1999, 21). Instead he specifies the core problem, which seems to be the speech's length. ${ }^{16}$ Why? Socrates' initial response to Protagoras' words is telling. Long speeches, he says, are enchant-

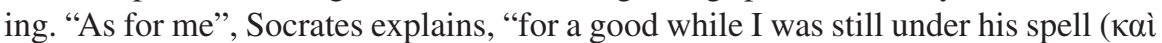

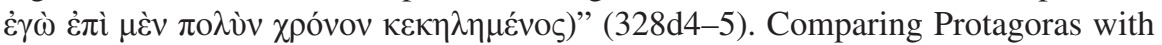
Orpheus, with whom Protagoras has just likened himself (316d8), Socrates describes Protagoras and his voice ( $\varphi \omega \vee \eta$ ) in terms of their power to charm and beguile

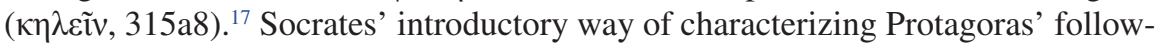
ers emphasizes this critique. As if in some bewitched trance, they dance around him.

\footnotetext{
${ }^{15}$ So Woolf $(1999,22)$. For discussion in relation the Phaedrus, see Ferrari (1987) and Pettersson (2013).

${ }^{16}$ There are five longer speeches in the dialogue, excluding Socrates': 316c6-317c5; 320c2-328d2; 334a3-c6 (Protagoras); 337a1-c4 (Prodicus); 337c6-b2 (Hippias). In these speeches it is possible to identify a variety of rhetorical techniques. Three are explicitly mentioned: (1) enchantment (328d4-5), (2) argument ad populum (334c7-8), and (3) diversion (336c4-d2). Despite Socrates' critique of long speeches he sets forth eight by himself: 319a8-320c1;342a6-347a5; 347b8-348a9; 348c5-349d1; 352a1-c7; 354e3-356c3; 356c4-e4; 356e5-357e8. For a lucid discussion of Socrates' use of long speeches, see Benitez (1992, esp. 240).

${ }^{17}$ The deceptive character of discourse is also reflected in Protagoras' account of the origin of language. Besides being disassociated from the arts of social interaction and cooperation, we also learn that language is a stolen gift. Taken by Prometheus from the building of Athena and Hephaestus - the two deities endowed with the greatest of cunning ( $\mu \tilde{\eta} \tau \imath \varsigma)$ - it was given to humanity in stealth. For discussion, see Vernant and Detienne (1974). In Protagoras' biographical comments, he also explains in what way sophistry is, and has always been, a matter of stealth and disguise (e.g. 316d6).
} 
They "follow where the voice sounds" (315b1). Just like books, without offering the opportunity for questions and answers - a method on which Socrates soon shall come to insist - Protagoras' long speech does not promote critical scrutiny. Instead, just like the sound from a gong, it is designed to drown all other voices but its own. As we soon shall see in some detail, Socrates has reasons to doubt the benevolence of Protagoras' voice.

In a second passage, Socrates outlines a further danger. In terms of his and Protagoras' attempt to interpret a poem by Simonides - on what is means to be a good person - Socrates explains that this mode of discourse is dangerous because it gives the appearance of being able to accomplish something that it cannot accomplish. It is presumptuous.

It seems to me that conversation about poetry is just like the gatherings of the vulgar and ordinary human. Without being able to be together with each other by themselves, when they are drinking, using their own voices and their own words, because they lack education, they enjoy flute-girls, contracting the many voices of the flute, and through these voices they are together. But when those that gather are beautiful and good, because they have a good education, you would see neither flute-girls nor dance-girls not harp-girls, for they [the well-educated] are together in an appropriate way with each other, without ornaments or entertainment, and they speak and listen to each other in turn in an orderly fashion, also when they have been drinking. This gathering [of ours] is such, that is, if it consists of men of that kind that many of us claim to be. It does not need alien voices or poets, who one cannot ask about what they are saying. When such things are introduced into the discourse, many say that the poet means this, and others say that the poet means that, because they are conversing about a matter that cannot be put to the test. But educated men avoid the delight of being together in that way. Instead they are together with each other through one another, using their own voices, and they put each other to the test in turns. (347c3-348a2)

In contrast to the act of conversing by means of your own voice, Socrates outlines the dangers of interpretation. Just as the first passage, these words seem to have a specific target. As pointed out by Raphael Woolf, "[Socrates'] immediate target is the reading and interpreting of poetry, as represented by Simonides' poem; but of course the criticism applies in principle to any form of written word". ${ }^{18}$ With a subtle yet clearly self-critical tone, Plato offers his readers reasons to doubt that an object of an interpretative act can express an independent teaching of its own. As we soon shall see in some more detail, Socrates does not only argue that it is impossible to determine the meaning of a voice that has been dissociated from its source. By means of staging his own interpretation, he also exposes the presumptions involved in such an endeavor.

Besides the dangers of deceitful speech and presumptuous interpretation, Plato does also make Socrates specify a third discursive hazard. In the light of Socrates' wish to find out what virtue is, and whether or not it can be taught, the conclusion is clear. Because it distracted the investigation from its proper course, Socrates' conversation with Protagoras has turned out to be dangerously topsy-turvy (cf. 361c3:

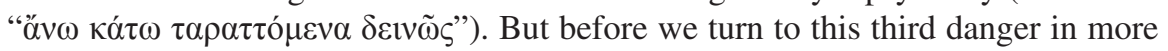
detail, let us first take a closer look the first two.

${ }^{18}$ Woolf $(1999,22)$. So also Trivigno $(2013,541)$. 


\section{Long Speeches}

Although there may be reasons to consider Protagoras' speech to be more consistent and subtle than Socrates seems to allow, ${ }^{19}$ and even if Socrates claims that he does not mistrust Protagoras' capacity to defend himself when questioned (329b1-5), Socrates' critical attitude towards long speeches is beyond doubt. Just like books, we learn, they aim to sway their addressees by bypassing the possibility of questioning and answering. In this sense they are deceptive. But what exactly are the mechanisms involved here? And what is at stake?

If we look at Socrates' concise way of articulating his critique in the light of its explicit target (viz. Protagoras' Great Speech) and Protagoras role as a teacher, one plausible account emerges. As has been argued, most recently by Francisco Gonzalez, Protagoras has reasons to defend his practice as an expert and teacher of virtue without offending the democratic point of view of his potential customers. ${ }^{20}$ But this, as we shall see, he cannot do without hiding his true intensions. Protagoras speech is deceptive in this sense. And Socrates sees it all along.

In reply to Socrates' suggestion that virtue cannot be taught - with virtue here

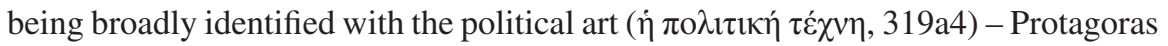
answers that Socrates has missed the point. ${ }^{21}$ The fact that the Athenian assembly does not call in experts when it comes to political matters, as Socrates has just pointed out (319b-e), is not a sign that there is no art to be taught. ${ }^{22}$ Instead, Protagoras explains, virtue is democratically distributed. In contrast to the other arts, given to man by Prometheus, Zeus decided to give political virtue ( $\dot{\eta} \pi \mathrm{o} \lambda \iota \tau \iota \kappa \dot{~}$

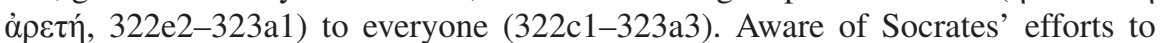
oppose him to the democratic point of view of the Athenians, Protagoras avoids undermining the legitimacy of their constitution. ${ }^{23}$

In order not to undermine the legitimacy of his own art, Protagoras will however also need to defend the opposite position, namely that there is need for his expertise.

\footnotetext{
${ }^{19}$ E.g. Garver (2004), Gagarin (1969, 48), Jowett (1953, I.119-31), and Adkins (1973). See also Lavery (2007).

${ }^{20}$ Gonzalez (2000, 117ff.). So also Stokes (1986, 235). See also Hemmenway (1996) and Adkins (1973).

${ }^{21}$ Since it is not established what virtue is, it is hard to pinpoint exactly against what Protagoras is

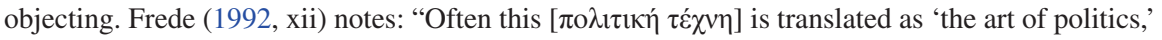
but, from the context, what Protagoras has in mind is perhaps rather the art of the citizen, the competence that makes a citizen a good citizen (cf. 319a4-5), part of which is to run one's household properly". As pointed out by Griswold $(1999,299$ n46) in view of the sophist's detachment from citizenship, travelling from city to city to sell his goods, the claim that Protagoras considered virtue to be a matter of citizenship rings somewhat hollow.

${ }^{22}$ Vlastos $(1956, \mathrm{x})$ points out that Socrates' silent premise here is that an art is something that is "taught to a few by a few".

${ }^{23}$ So Gonzales $(2000,117)$. See also Taylor (1976, esp. 83) or Stokes (1986).
} 
In reply to another claim that Socrates makes - that the best citizens cannot teach virtue to their sons - Protagoras proceeds to argue that there is something called

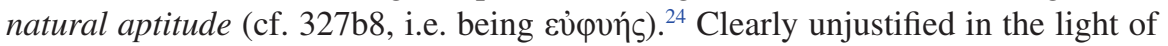
his preceding myth, Protagoras compares the art of politics with the art of fluteplaying. Just as in the case of excellent flute players there is no reason to think that the best citizens beget the best children (327bf). Aptitude pops up here and there. And, if someone - like Protagoras (328b1-2) - shows signs of being a little superior, one should be grateful.

Although Protagoras presents this point as in line with his myth, this coherence does not seem capable of holding up under further scrutiny. As Socrates points out, however, the length of Protagoras' speech makes any such scrutiny practically impossible (328e5-329b1). The simple conclusion we can draw from this limitation is however important. For even if there may be reasons to think that Protagoras' speech has other and more subtle virtues, this line of thought may help us to understand Socrates' worry. Socrates' identification of the charming and deceptive nature of long speeches can be understood in terms of their stealth and lack of argumentative transparency. Protagoras' speech shows clear signs of making its point by covering up its inconsistencies; and Socrates worry can thus be understood in terms of the generalized idea that long speeches are persuasive by their ability to hide their true intensions.

There is another passage in the dialogue that emphasizes this point further: Socrates' own "great" speech. Introduced at 310a7, as an account of his and Hippocrates' early morning meeting and their subsequent encounter with Protagoras, the speech does not end until the dialogue does (at 362a4). In the light of Socrates' efforts to undermine and change Protagoras' preference for long speeches, it soon becomes clear that also Socrates' own long speech is deceptive.

Socrates' explicit attempt to cast doubt on Protagoras' preferred mode of discourse, viz. long speeches (328e5-329b1), is supplemented by an argument from pity, beginning at $334 \mathrm{c} 6$. Here, Plato makes Socrates appeals to the compassion of his audience. As an attempt to dismiss Protagoras' argument for the multiform

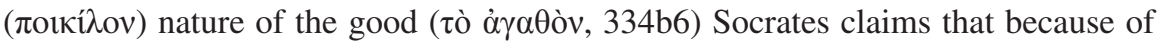
the length of Protagoras' defense, and his own forgetfulness, the mode of the present argumentation must change. Instead of long speeches, Socrates wants the discussion to consist of short questions and equally short answers. Protagoras, however, is not that easily persuaded, and as a consequence Socrates stands up and claims that he should leave (335c8). This behavior results in a negotiation of the formal rules of the discussion (335c8-338e2) and Protagoras eventually agrees to keep to short questions and answers (338e2-5).

Leaving aside Socrates' reasons for wanting to disrupt the argument at this point, the deceptive nature of Socrates' "great" speech should nevertheless be clear. Socrates' appeal to forgetfulness is a trick. Although it is easy to fall for Socrates'

${ }^{24}$ According to Schofield $(1992,128 n 8-9)$ neither this, nor Socrates' first objection against the teachability of virtue, are original: The first was a well-known topic of sophistic debate. The second is to be found in Dissoi Logoi (Diels-Kranz 90.6). 
charm, it is clear that he is not honest, because it is beyond doubt that Socrates is able to remember more than one Stephanus page of argument. Socrates is not trying to express his honest beliefs (as suggested at 331c4-d1). And even if we might accept Socrates' argument from pity anyway, as Alcibiades seems to do (336d2-4), Socrates' critique of the deceptiveness of long speeches seems to be confirmed also by his own words. ${ }^{25}$

\section{Interpretation of Poetry}

If what has been stated above is on target, Socrates considers long speeches to be dangerous because they are deceptive. This danger may however seem to be easily counteracted. By means of analysis and interpretation one should be able to detect cunning tricks and inconsistencies. Within the framework of the new rules of communication established after Socrates' attempt to leave (335c8-338e2), the Protagoras also offers two telling examples of how interpretation and analysis can expose contradictions and disguised motives: Protagoras' analysis of Simonides' poem, on what it means to be a good person; and, Socrates' own. ${ }^{26}$ Eventually, Socrates will of course draw the conclusion that also this discursive mode is problematic. Just like the interpretation of any text, discussion of poetry will turn out to be presumptuous. In order to understand why Socrates draws this conclusion, let us take a closer look at some parts of the passages that exemplifies this practice.

Having agreed to keep to short questions and answers, Protagoras continues in a more conversational mode by asking Socrates to react to his interpretation of the poem (339a5). Vindicating his interpretative effort by the claim that "the greatest part of a man's education is to be skilled in the matter of verse" (338e6-339a1), Protagoras explains that Simonides' poem is inconsistent.

First he [Simonides] laid it down himself that it is hard for a man to become good in truth

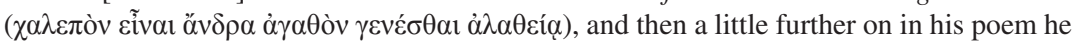
forgot, and he proceeds to blame Pittacus for saying the same as he did - that it is hard to be good ( $\chi \alpha \lambda \varepsilon \pi$ òv $\dot{\varepsilon} \sigma \theta \lambda$ òv $\varepsilon \mu \mu \varepsilon v \alpha 1)$, and refuses to accept from him the same statement that he made himself. $(339 \mathrm{~d} 1-6)^{27}$

Socrates' answer, and his own interpretation of the poem, can be analyzed in three parts. ${ }^{28}$ The first (339e-342a) briefly defends the poems' consistency in arguing that

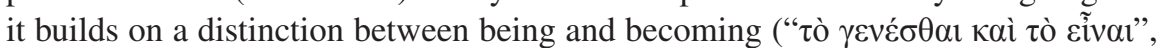

\footnotetext{
${ }^{25}$ The two modes of deception exemplified by Protagoras' and Socrates' "great" speeches, enchantment and diversion, are mentioned at 328d4-5 and 336c4-d2. For discussion, see Benitez (1992, 240).

${ }^{26}$ The poem is reconstructed and translated by Bowra (1961, 326-36). Cf. McCoy (1999, 365n6).

${ }^{27}$ My italics. Translation by Lamb (1967).

${ }^{28}$ So Frede $(1986,739)$. It is divided differently in McCoy $(1999,352)$ and Trivigno $(2013,515)$.
} 
340b5). The second (342a-343c5) concludes with the claim that Simonides' purpose was to undermine the wise Pittacus' authority and gain a reputation of being wise himself $(343 \mathrm{~b}-\mathrm{c}) .{ }^{29}$ The third continues the defense of Simonides. Let us look at a few telling moves in the third part. ${ }^{30}$

One line from the poem is crucial: "It is hard to be good ( $\chi \alpha \lambda \varepsilon \pi$ òv $\dot{\varepsilon} \sigma \theta \lambda$ òv $\varepsilon \tilde{\mu} \mu \varepsilon v \alpha 1)$ " (343d4). According to any standard interpretation, Simonides ascribes this line to Pittacus and objects by saying that this cannot be right, because only the gods can be good. ${ }^{31}$ The permanent condition of being good is not hard to reach, but impossible. Subject to great external forces, a human can only be good for a moment. Identifying the conditions of goodness with something like "wealth, physical attractiveness and power" (McCoy 1999, 351), this means that what decides whether a person is able to be good, or act well, depends on fortune and misfortune.

Another line states the poems' moral conclusion: "But I praise and love everyone

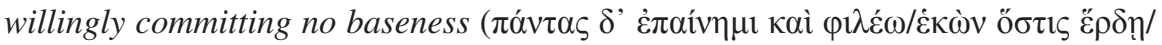

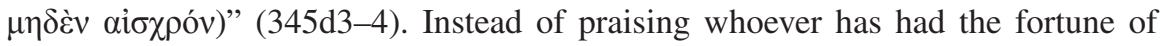
being able to act in a good way, we should praise the one who does not deliberately try to be bad.

Socrates does not endorse this reading. First, he claims that Simonides does not reproach Pittacus for saying that the conditions of goodness cannot be wealth, physical attractiveness and power, but that Simonides reproaches Pittacus for saying that the conditions of goodness cannot be knowledge. Second, this implies that Simonides does not mean to say that we should praise the one who does not do wrong willingly, but that it is knowledge we should praise, and the one who has it. In order to reach this unforeseeable conclusion Socrates' argument goes through several steps. The following are revealing of his purpose.

First, he argues that misfortune cannot influence someone that is already bad, "just as you cannot knock down one who is lying down" (344c7-8). Only someone

\footnotetext{
${ }^{29}$ This second part has a comic ring. In the light of Socrates' earlier declaration that he wants to converse by means of short questions and answers, and further, with regard to the fact that he was going to answer in an exemplary way (338d), the length of Socrates' speech must to be some kind of joke.

${ }^{30}$ There are many excellent commentaries on Socrates' (and Protagoras') reading of Simonides' poem. See, e.g., McCoy (1999), Trivigno (2013), Frede (1986), and Pappas (1989). My purpose of bringing this up is not to develop a new reading, but only to lay bare how Socrates' interpretation of the poem corresponds to his own critique of interpretation.

${ }^{31}$ In reference to Bowra (1934) and Woodbury (1953), McCoy $(1999,351)$ argues that most commentators, except Socrates (as we shall see), read the poem along these lines: "Most commentators see Simonides poem as presenting the following view: excellence as traditionally understood (e.g., possessing the traits of wealth, physical attractiveness, and power) is difficult to attain and impossible to keep for long. Because human beings universally act badly in the face of misfortune [...]

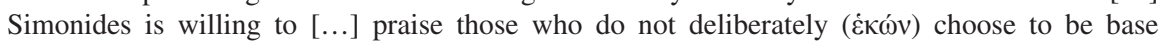
( $\alpha i \sigma \chi \rho o ́ v) . "$
} 


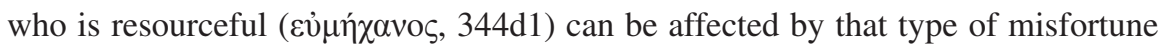

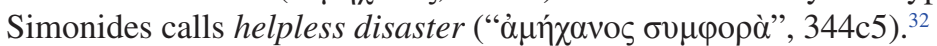

Second, Socrates investigates what we should take such misfortune or disaster to mean. In analyzing the relevant line in Simonides' poem - "If he has fared ( $\pi \rho \alpha \dot{\xi} \alpha \varsigma)$

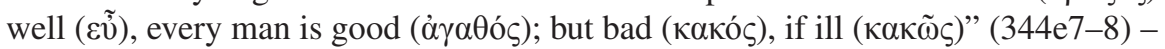

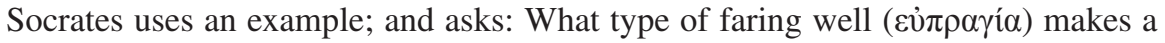
doctor good ( $\dot{\alpha} \gamma \alpha \theta$ ó, 345a2)? Phrased in negative terms, Socrates answers that the only thing that can make a doctor fair ill is the loss of knowledge ( $\dot{\varepsilon} \pi 1 \sigma \tau \eta \mu \eta \eta, 345 b 5)$.

Third, having thus established knowledge as the condition of goodness, Socrates draws the conclusion. Against any standard reading, he argues that Simonides does not conclude that "I praise and love everyone willingly committing no baseness

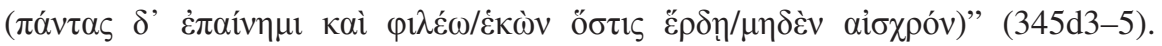
Dismissing, in passing, the thought that it is possible to do bad by intent

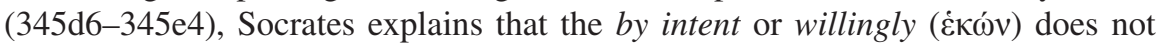
describe the motivation of the person performing the act, but the motivation of Simonides. Socrates reads the willingly ( $\dot{\varepsilon} \kappa \omega ́ v)$ together with the "I praise and love

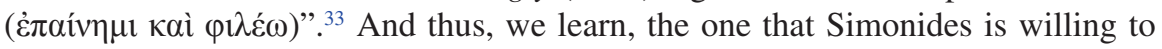

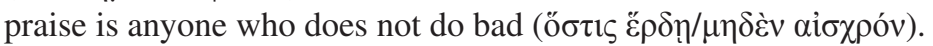

Fourth, in the light of Socrates' former arguments, this position is not as uncontroversial as it may seem. Having shown (1) that misfortune can only influence someone with knowledge, (2) that only such a person can ever do any good, and (3) that a permanent state of goodness is impossible for a human, Socrates' conclusion, that those whom Simonides is willing to praise are the-ones-in-between (cf. 346d3: $\tau \grave{\alpha} \mu \varepsilon \dot{\varepsilon} \sigma \alpha)$, implies that they are persons with knowledge (cf. 346d1-2). ${ }^{34}$

Let us now step back a little and ask what is going on in these passages. What is Socrates doing? Despite the wide range of different interpretations, there is a basic consensus. ${ }^{35}$ Socrates is not only "systematically misreading Simonides" (Pappas 1989, 249), but, "at the expense of honest hermeneutics" (McCoy 1999, 355), he "distorts the text" (Trivigno 2013, 520) and "imposes, consciously and forcefully, his own tenets on the poem" (Frede 1986, 740). ${ }^{36}$ But how is this possible and what is the point?

First, it is clear that both Protagoras and Socrates exploit the poem. This point is also emphasized by their agreement to play by the same rules. While Protagoras uses the poem to show off his skill in the matter of verse (338e6-339a1, cf, Trivigno

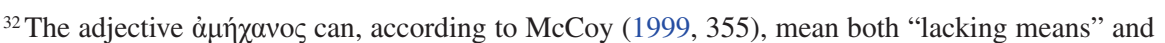
"being such that no means will do", the latter being used here. Cf. Trivigno $(2013,522)$.

${ }^{33}$ Cf. Trivigno (2013, 521 and 523) and Pappas (1989, 250).

${ }^{34}$ The type of knowledge at stake here is controversial. It is however beyond the scope of this paper to adjudicate the debate. For discussion, see McCoy (1999), Frede (1986), and Trivigno (2013, $525)$.

${ }^{35}$ As pointed out by Pappas $(1989,249)$ and Trivigno $(2013,520)$.

${ }^{36}$ At a first glance, Frede may seem to oppose this general agreement, arguing that Socrates' reading of Simonides' poem is "basically sound" (737). Later (740) she does however add that this in not supposed to "imply that Socrates really thinks that he is rendering Simonides' own intentions".
} 
2013), Socrates uses it to sanction a set of tenets alien to the poem (Frede 1986, 746; cf. Pappas 1989). As Socrates soon comes to point out, however, this instrumental treatment presumed too much; and was, therefore, dangerous. Their contest of interpretation presupposed that there was a definite and consistent message to be extracted from the poem (339b6-9, cf. McCoy 1999, 353; Trivigno 2013, 516). And accordingly, their contest also assumed that it was possible to extract a message from a medium that, at least according to what Plato makes Socrates say, cannot carry such a load. For although, as Socrates puts it, "many say that the poet means this, and others say that the poet means that", he makes it perfectly clear that this is just because they are "conversing about a matter that they cannot put to the test

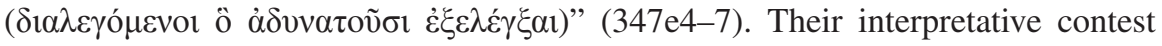
was presumptuous because it claimed to be able to accomplish what could not be accomplished by means of the established rules.

Whether or not Socrates is right in this, it is at least reasonably clear that Socrates is not only trying to tell Hippocrates why intercourse with Protagoras is dangerous, he also wants to show him this. When uncared for and exploited, no written text offers any message to be put to the test. But interpretative endeavors such as the ones we are offered make us think otherwise. And this is dangerous, not only because they build on a set of presuppositions that dissociate speaker and voice, but also because they sanction the treatment of the voice as merchandise.

\section{Short Questions and Answers}

So far we have seen that Socrates has reason to consider two modes of discourse hazardous. Long speeches are deceptive and interpretation of poetry presumptuous. Accordingly, and as Socrates is often taken to insist, there seems to be only one viable alternative left: short questions and answers. The more conversational parts of the dialogue are also often labeled dialectical and taken to be Socrates' preferred mode of discourse. ${ }^{37}$ But Socrates' final verdict of his conversation with Protagoras seems to tell otherwise. Despite the fact that the discussion has progressed by asking and answering questions, it has missed its target entirely. Indicative of the purpose of Plato's text, Socrates leaves little room for doubt. The results of the

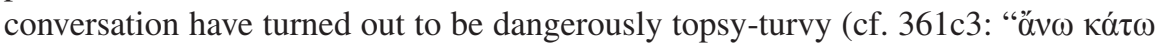

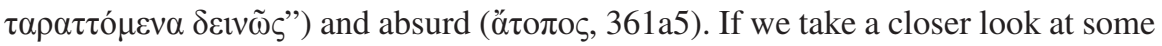
parts of the dialogue that exemplifies the mode of discussion that is at stake here,

\footnotetext{
${ }^{37}$ E.g. Long (2005, 3), Gonzales (2000, 132f), and Benitiez (1992, 242). Benson (2006) argues that the substantive expression, $\dot{\eta} \delta 1 \alpha \lambda \varepsilon \kappa \tau \iota \kappa \eta$, is not frequent in Plato, while the infinitive is. In the

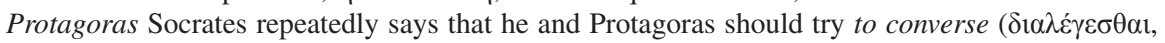
e.g. 316c3). This expression (used 32 times) is translate by Notomi $(2004,1)$ as "engaging in dialogue". The difference between Socrates and Protagoras' use of this terminology is discussed by Burnyeat (2013, 419ff.). See also Benson (2006) and Robinson (1953b).
} 
Socrates' reasons to consider himself entitled to draw this conclusion becomes clearer.

At around 348c5, the dialogue begins to pursue in a more conversational manner. After a short summary of Protagoras' view on the unity of the virtues (349b1-349c5), Socrates asks whether Protagoras has changed his mind. Protagoras answers that

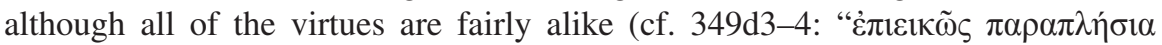

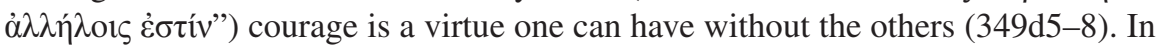
his reply to Protagoras, Socrates poses a series of questions designed to undermine Protagoras' position.

Socrates' first attempt (349e1-350c5) is telling for what shall come. On the assumption that courageous men are bold, and in getting Protagoras to admit that divers and horsemen with knowledge are bolder than those without, Socrates begins by trying to make Protagoras accept the thought that it must be knowledge that distinguishes courage. Since there are men without knowledge who nevertheless are considered to be bold, as Protagoras concedes, Socrates pushes Protagoras into saying that these men must be mad. And since Protagoras cannot allow himself to admit that mad men can be courageous, there is only one alternative left: knowledge. Since (1) courageous men are bold, (2) knowledge decides a man's level of boldness, and (3) mad men cannot be courageous, it seems to follow that knowledge distinguishes courage. And thus, on the assumption that knowledge and wisdom can be equated, Socrates tries to lure Protagoras into admitting that courage is not possible without wisdom. ${ }^{38}$ Protagoras is, however, not such an easy prey; and, as we know, he catches Socrates in the act (cf. 350c5-351b2). Protagoras sees that Socrates is trying to deceive him: If one can draw the conclusion that courage is not possible without knowledge from the thought that knowledge conditions courage, he says, it should also be sound to claim that it is not possible to be strong without knowledge. In wrestling, Protagoras points out, someone that knows how to wrestle is clearly more powerful than someone that does not. But even if this is true, and knowledge makes one wrestler more powerful than another, it is nevertheless absurd to conclude that one cannot be strong without knowledge. Even if knowledge may help to make a person bold, courage cannot be knowledge.

At this stage of the discussion, Socrates abruptly breaks the argument off (351b3). Without further comments, he changes the subject. The silence is telling. It is clear that Protagoras is not that easily deceived. Socrates need to be more refined than so-far to get Protagoras where he wants him. Socrates' proceeding argument is also much more sophisticated than the first.

Socrates begins again by trying to make Protagoras accept the thought that to live in pleasure is to live well. Protagoras' unwillingness to agree to this, without qualification, triggers a further argument to the same point. First, Socrates commits Protagoras to the claim that knowledge is the most forceful power ( $\kappa \rho \alpha$ q $\tau 1 \sigma \tau o \zeta$, $352 \mathrm{~d} 2$ ) in human action (352c8-d3). And then he goes on to ask whether Protagoras agrees with the opinion of the many ("oi $\pi \mathrm{o} \lambda \lambda \mathrm{oi}$ ", $352 \mathrm{~d} 5$ ), that is, insofar as they

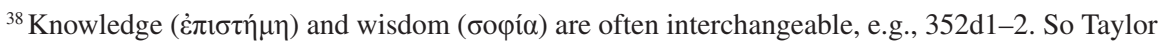
$(1976,152)$. 


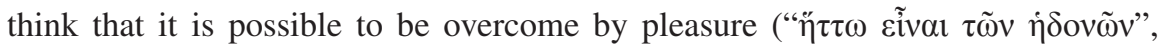
$353 \mathrm{c} 2$ ), even if one knows that what one is about to do is bad (cf. 353c7:

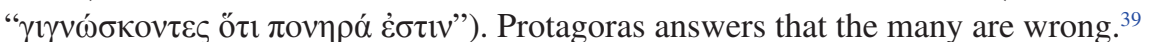

Symptomatic of the argumentative strategy at play, Socrates goes on to ask how badness is to be understood. Arguing that a temporary act of satisfying one' pleasures can result in future pains, Socrates concludes that the many cannot mean that

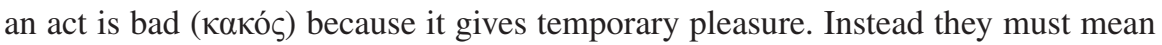
that the act is bad because it yields future pains (353d8-e1). Socrates then goes on to show that the principles of this hedonistic calculus must also be valid in the opposite case. And thus, since the many thinks that it is the sum of the pain/pleasure balance that determines the value of an act, they are apparently also committed to the thought that despite temporary pains - such as in gymnastics or war - an act is called good $(\dot{\alpha} \gamma \alpha \theta$ ó $\varsigma$ ), if its future results are pleasant, such as in health or wealth (354b1-5). ${ }^{40}$ Protagoras concedes.

The conclusion that Socrates draws from this is the following. The phrase being overcome by pleasure, really means being overcome by the good; and accordingly it would of course be absurd to claim that "a man does bad [...] because he is overcome by the good" (355d1-3). As Protagoras is now forced to admit, the many are confused. And Protagoras agrees that it is reasonable to think that the good is some form of pleasure (356c3).

After a shorter elaboration of this argument in terms of an art of measurement (often taken to further establish the connection between the hedonistic calculus and knowledge) Socrates returns to courage and wisdom. ${ }^{41}$ By first opening up the argument to objections, but without getting any, Socrates establishes an argumentative consensus to the effect that the good is to be considered to be some form of pleasure (354e8-355a4, cf. 354c3, 354d1-4 and 354b8-c2); and then goes on to ask what makes a man coward. Fear, he proposes, is the expectation of something bad. The proper example, we learn, is war. But since war, as Protagoras certainly thinks, is something honorable ( $\kappa \alpha \lambda$ óv, 359e5), it appears to be something good. Without questioning this premise, Socrates goes on to say that since the good is taken to be some form of pleasure, war must also be pleasurable. Accordingly, Socrates can also explain why the coward runs away from the battle-field. He is ignorant. Without being able to estimate the proper pain/pleasure-balance, he does not know what is to be feared. But the brave one does. He sees the pleasures waiting for him at the battle's end. And, thus, since courage is the opposite of cowardice, courage is wisdom.

\footnotetext{
${ }^{39}$ On Socrates' use the imaginary interlocutor, see Gonzales (2000) and Moss (2013). Schofield $(1992,134)$ argues the fictive opponent in invented so as to forge an artificial solidarity between Socrates and Protagoras.

${ }^{40}$ As pointed out by Frede (1992, xxviif), it is not clear what type of hedonism Socrates presupposes here.

${ }^{41}$ For discussion, see McCoy (2008, esp. 57), Brickhouse and Smith (1997), Hackforth (1928), and Irwin (1977).
} 
In the light of what happens in this argument, Socrates' conclusion that his conversation with Protagoras has turned out to be dangerously topsy-turvy may seem to be less strange than at first sight. With regard to Socrates' critique of long speeches and interpretation of poetry, Socrates is clearly aware of the dangers of deception and presumptuousness. Socrates' strategy in this argument is however not much better. There are at least three reasons.

First, the details of Socrates' line of reasoning reveal that his argument was not particularly transparent. Besides the seductive use of an imaginary interlocutor, there are clearly argumentative options that Socrates omits. The fact that bad acts can be traced to ignorance, for example, does not require that courage be the same as wisdom. For even on Socrates' hedonistic calculus, it is still possible that the future pleasures resulting from running away from the battle-field may be greater than the pleasures resulting from staying. There is no necessary connection established between running away and future pains, in the same sense as there is a necessary connection between gluttony and future pains, for example (cf. Moss 2013, 27f.). In addition, the entire argument to the effect that the coward is ignorant is based on a premise that Socrates, just a few pages above, has denied (341b1-c2). With the aid of Prodicus, Socrates made it perfectly clear that war is to be consid-

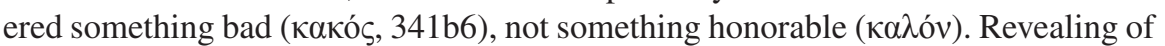
what is going on in this argument, this is a point that Socrates now remarkably appears to have forgotten.

Second, the deceptive nature of Socrates' words is also apparent in the general form of his argumentative strategy. Although Socrates repeatedly insists on the noncompetitive ambition of his questions, there are strong reasons to doubt his sincerity. Besides the fact that he actually manages to win the argument (360d5-e5), Protagoras also admits his lost (cf. 361d4-362a1). The conversation about courage and wisdom has clearly not been any kind of joint search. It has been a competition. And from this point of view, its lack of argumentative transparency is not surprising. Socrates does not try to make all the options and steps of the argument evident, so as to secure that Protagoras understands the deductive moves of the inquiry, because Socrates is not trying to make him follow. He is trying to make him contradict something he has said before. By first probing for Protagoras' level of competence, Socrates goes on to launch an attack that eventually will make his opponent give in.

Third, even if one may be inclined to argue that Socrates' argument is not deceptive, but only lacking, one must take the following points into consideration. Besides the fact that the conclusion Socrates draws regarding courage and wisdom builds on assumptions that he does not allow elsewhere, neither in the Protagoras (341b1-c2) nor in other dialogues (e.g. Gorg.494e9-497a5, Rep.505b5-11 or Phil.20e4-21a2), this conclusion is of course also incompatible with the dialogues' aporetic end. If the conclusion that courage is wisdom would have been reached by the proper means, Socrates would have no reasons to doubt its validity. But Socrates makes it perfectly clear that he has. In addition, if Socrates' conversation with Protagoras would have been correctly oriented, one could have expected Socrates to show some awareness of the limitations of their pursuit. Instead of offering a presumptuous account claiming to have established something it did not have the means to estab- 
lish, the conversation should have been performed in a discursive mode able to properly asses its own accomplishments. Yet, it is clear that we have nothing of that sort. On the grounds that the question of the quality of virtue was asked before the question of its being was even posed, Socrates says that if they are to investigate the subject matter in a proper way, they will need to start anew (361c4-6). ${ }^{42}$ However important a lesson this may be, it seems reasonable to say that Socrates, at least, would not want to describe the conversation in the Protagoras to be an example of proper dialectic. But what is it then?

\section{A Sophistical Practice}

As Michael Frede has argued, there are two important things to keep in mind. First, the conversation between Socrates and Protagoras in the Protagoras cannot be seen in isolation. Rather, it should be understood as an example of a larger sophistical practice. ${ }^{43}$ The rules are simple. In trying to get the respondent to contradict a formerly given statement, one person asks the questions and the other answers with yes or no. According to Frede "Socrates' mastery of this practice is such that he manages to 'refute' the respondent even where we have some reasons to believe that Socrates actually shared the respondent's view". ${ }^{44}$ Second, even if there are reasons to think that the Protagoras contains examples of proper Socratic tenets, we cannot be sure, because "Socrates could manage to refute any thesis". ${ }^{45}$ According to Frede, there is, however, one thing that we can be more certain about. The conversation in the dialogue is part of a tradition. It is part of a tradition that is supposed to stand in contrast to the one Plato wanted to establish. And if this is correct, Plato certainly had reasons to include also the discursive mode of short questions and answers in the dialogue. In accordance with Socrates' ambition to show Hippocrates the hazards of his trust in discursive proficiency, Plato had reasons to show his readers that there is no guarantee that short questions and answers will put you on the right path. When an inquiry is pursued along the lines of Socrates and Protagoras' conversation, conversation can be just as dangerous as long speeches and interpretation of poetry can be. The briefness of its questions and answers may give the appearance of making all the steps of the investigation transparent. And in pursuing its path by means of agreement or consensus it can give the appearance of being on the right track (Pace Long 2005). But, just as in the case of long speeches, these appearances

\footnotetext{
${ }^{42}$ Politis $(2012,223)$ puts it accurately: "[I]f they [Socrates and Protagoras] want the inquiry to arrive at a clear, manifest and stable outcome, they must change their line of inquiry". So also Taylor (1976) and Guthrie (1961).

${ }^{43}$ Frede $(1992$, xvff). Nehamas $(1990,5)$ agrees, questioning a tradition going back to Sidgwick and Grote.

${ }^{44}$ Frede (1992, xvii). E.g. Protagoras' refuted attempt to reject hedonism. Cf. Gorg. 494e9-497a5, Rep. 505b5-11 or Phil. 20e4-21a2. For discussion, see also Moss (2013).

${ }^{45}$ Frede (1992, xvii).
} 
are deceptive. The conversation may hide its gaps and traps in long and complex arguments that, in retrospect, can be said to be just as presumptuous as interpretation of poetry. Because insofar as Socrates is right in claiming that both his own and Protagoras' contributions were quite out of place (ö $\tau 0 \pi \mathrm{o},, 361 \mathrm{a} 5)$, it is clear that their particular mode of discourse distracted the inquiry from it proper course.

\section{Conclusion: Dangerous Voices}

In line with Socrates' initial warning to the young Hippocrates of what may happened when one involves oneself with a sophist, we have seen that Socrates' critique of long speeches, discussion of poetry and short questions and answers are not only possible to understand in terms of their deceitful, presumptuous and distracting characteristics. The dialogue also stages these three modes of discourse in a way that lets us appreciate Socrates' reasons to worry. But this calls for a concluding question: Are the three criticized modes of discourse just random cases, or are they chosen, with care, to emphasize some common problem?

As we saw at the outset of this paper, the three passages were Plato makes Socrates articulates his worries are all phrased in self-critical terms. The target of Socrates' critique of long speeches applies to any form of discourse similar to what may be expressed in a book. His critique of interpretation of poetry applies, in principle, to any form of written word. And Socrates' final evaluation of the accomplishments of his conversation with Protagoras shows all the signs of being a self-critical assessment of the outcome of Plato's text. In all of these passages the written word seems to be the paradigmatic target of critique.

As we have seen, in his critique of long speeches Socrates also emphasizes the difference between what is spoken and what is written. But this difference is carefully qualified. Just as Socrates insists in the Phaedrus (e.g. 259e1-6, 275c3-d2, 276a5-6 and 277e5-278b4), the difference between what is spoken and what is written is not always coextensive with voice and text. In the form of public speeches or rhetorical display, the spoken word is liable to the same charges as what may be written in a book. And although Socrates' critique of interpretation of poetry emphasizes the difference between the exercise of you own voice and the act of textual interpretation, Socrates' final evaluation of his discussion with Protagoras, I have argued, shows that a spoken conversation can be just as deceptive as a book, or just as presumptuous as an act of interpretation. Accordingly, it does not seem to be the paper and the ink that is the problem, but some feature of language and discursive interaction that can be represented by a text.

In order to pinpoint what this feature is, Socrates' introductory conversation with Hippocrates is telling. ${ }^{46}$ As we have seen, one central point of Socrates' argument here is that Protagoras treats his voice as merchandise. Just as Socrates presumes in

${ }^{46}$ For a lucid discussion on how Socrates' initial conversation with Hippocrates is designed to prepare the reader for what the rest of the dialogue shall offer, see Schofield $(1992,125 f$.). 
his mock interpretation of Simonies' written poem, Protagoras considers his teachings to be products with a message that can change hands without any loss of content. In this light, a text seems to be the perfect paradigm for the results of discursive commodification. Dissociable from its source of origin, just like Protagoras' teachings, it is treated as independent and self-contained. And it has no indispensable link to its originator. But this, of course, is problematic, because as Socrates suggests in his critique of interpretation of poetry, no text can carry such a load. If we want to know what thought the text is designed to capture, we will need to talk to its author. Why? Insofar as we can assume that there are no texts with souls, the reason seems to be clear. Only souls can entertain thoughts. But what does this mean? One suggestion would be that while an ensouled voice can be said to be conditioned by an internal difference that allows it to take itself as an object of thought, a text is simple and one-sided. Self-evident as it may seem, a text does not have access to the internal operations by means of which its expressions have come to be formed, and it cannot see beyond its own position, however subtle and self-critical this may be. But all voices that are treated as texts share this lack. Just as long speeches and premeditated positions, texts are one-directed. They cannot adapt to their counterparts and they cannot choose their words with care of theirs addressees' point of view. They can only speak, not listen. In a more Platonic vocabulary this would mean that a voice that is treated as a text is denied the ability to entertain a dialogue; an ability without which it becomes thoughtless. It cannot nourish and sustain the unassuming conditions of an open-ended investigation. Instead, it can only represent a certain position. And in contrast to a voice that is open to dialogue, a voice that is treated as a text is only open to competition and exploitation.

As we have seen, in the examples of the three distinct modes of discourse that Socrates criticizes in the Protagoras, these ideas are confirmed. Not only is it clear that Socrates considers Protagoras' long speech to be an example of a type of discourse that lacks the ability to listen and answer to questions. Socrates' treatment of Simonides poem also shows what is at stake. Exemplified by his exploitation of its words, Socrates outlines the fate of desouled voices. Although they may seem to be able to communicate some important thought, this is just as charade. When distorted or criticized, they cannot continue the discussion by correcting the misunderstandings or admitting their mistakes. Instead they are at the mercy of the interpreter. And the voice of the text can be exploited for whatever end he prefers. Socrates' discussion with Protagoras extends these ideas to a spoken situation. Protagoras is considered to represent a certain preconceived position. And Socrates' exploitation of his voice confirms this view. Although he eventually admits the dangerous and absurd nature of their discursive competition, Socrates' actual treatment of Protagoras in the conversation is quite straightforward. In line with Protagoras' treatment of himself and his teachings, Socrates exploits the position Protagoras considers himself to represent. Indicative of the fact that he does not really think that Protagoras can or is willing to listen, Socrates shows no signs of being ready to tell the sophist his true intensions. Instead he deceives. Phrasing his arguments so as to align them with Protagoras' point of view, Socrates exploits whatever weaknesses he sees in Protagoras' position and uses this to win the game. But as the end of the 
dialogue makes clear, this is a failure. As it comes to success in the matter of virtue, the dialogue identifies no winners. And even if one may think that Plato just decided to illustrate this activity so as to warn his readers of the time-wasting effects of intellectual sports, Plato's account of Socrates' warning to Hippocrates suggests that the matter may be more serious. Phrased within the conceit of Plato's fiction, Socrates warns Hippocrates that his very soul is at stake. If one is not careful, we learn, the soul may get poisoned and corrupted by Protagoras' voice, just like bad food can poison and sicken the body. However, as should be reasonably clear by now, Socrates' warning is not confined to Protagoras' voice alone. Instead, it is designed to prepare the reader for what shall come. And as we have seen, the dialogue's account of the hazards of discursive commodification extends far beyond the sophist's teachings. All texts, it seems, and all voices that are treated as texts, share the same problem. By promoting the illusory stability of well-defined and independent positions, they undermine the virtue of a sensitive and attentive mode of discourse. By means of their deceptive charm, long speeches may paralyze the process of unassuming inquiry. By sanctioning the dissociation of voice and soul, interpretation of poetry promotes the presumptuous ideal of self-contained teachings; and conversations that promote the battle of positions replace the search for clarity with deception and trickery. All commodified voices are dangerous in this way. But Plato's text has some unusual features; and it is different from many others voices. By including a critique of the very medium by means of which it operates, it arms its readers with a set of tools that makes it possible to dismantle its deceptive charm. By means of its self-critical vein, or, as one scholar has described it, its internal self-contradiction (Woolf 1999, 28), the Protagoras promote thinking at the expense of teaching. Instead of asking us to chisel out its true meaning and live our lives accordingly, Plato's Protagoras suggests another alternative. Although stated very brief, the notion of a teaching, used to describe what Protagoras is selling, is contrasted to another type of knowledge. Against the background of Socrates' account of Protagoras' commodification of his voice and the dangers of discursive merchandise, Plato makes Socrates suggest that there is more to learn than teachings. Compared with the expertise of the doctor, Socrates outlines a type of knowledge that seems to be immune to commodification. For in granting its possessor the ability to evaluate what teachings are good and what teachings are bad, it seems to render all such teachings useless. If you already have the capacity to know what is good and bad for the soul, what use are teachings? Revealing of what the rest of the dialogue shall offer, Socrates never answers this question. And he never explains what this type of knowledge amounts to. Both Socrates and Hippocrates, we learn, "are still a little too young to get to the bottom of such a great matter" (314b5-7). And instead they go and talk to Protagoras. 


\section{References}

Adam, Adela Marion and Adam, James. 1893. Protagoras, with Introduction, Notes and Appendices. Cambridge: Cambridge University Press.

Adam, J., and A.M. Adam. 1893. Plato: Protagoras. Cambridge: Cambridge University Press.

Adkins, A.W.H. 1973. Arete, Techne, Democracy, and Sophists: Protagoras 316b-328d. Journal of Hellenic Studies 93: 3-12.

Benitez, Eugenio. 1992. Argument, Rhetoric and Philosophic Method: Plato's Protagoras. Philosophy and Rhetoric 25: 222-252.

Benson, Hugh. 2006. Plato's Method of Dialectic. In Blackwell Companion to Plato, ed. Hugh H. Benson, 85-100. Malden: Blackwell.

Benson, Hugh. 2009. Socratic Method [manuscript]. For Cambridge Companion to Socrates. Cambridge: Cambridge University Press.

Bowra, C.M. 1934. Simonides and Scopas. Classical Philology 29: 230-39.

Bowra, C.M. 1961. Greek Lyric Poetry. Oxford: Clarendon.

Brickhouse, T., and N. Smith. 1997. Socrates on the Unity of the Virtues. Journal of Ethics 4(1): 311-324.

Brickhouse, T., and N. Smith. 2007. Socrates on Akrasia, Knowledge, and the Power of Appearance. In Akrasia in Greek Philosophy: From Socrates to Plotinus, ed. C. Bobonich and P. Destrée, 1-17. Leiden: Brill.

Burnyeat, M.F. 2013. Dramatic Aspects of Plato's Protagoras. The Classical Quarterly 1(63): 419-422.

Bury, R.G. 1966. Plato in Twelve Volumes. Cambridge, MA/London: Harvard University Press/ William Heinemann Ltd.

Cronquist, John. 1975. The Point of Hedonism in Plato's Protagoras. Prudentia 12: 63-81.

Denyer, Nicholas. 2012. Review of The Development of Dialectic from Plato to Aristotle, ed. Jakob Fink. Notre Dame Philosophical Reviews. http://ndpr.nd.edu/news/46723-thedevelopment-of-dialectic-from-plato-to-aristotle. Accessed 8 September 2016.

Devereux, Danial. 1995. Socrates' Kantian Conception of Virtue. Journal of the History of Philosophy 33(3): 381-408.

Ferrari, G.R.F. 1987. Listening to the Cicadas: A Study of Plato's Phaedrus. Cambridge: Cambridge University Press.

Frede, Dorothea. 1986. The Impossibility of Perfection: Socrates' Criticism of Simonides' Poem in the Protagoras. Review of Metaphysics 39(4): 729-753.

Frede, Michael. 1992. Introduction. In Plato: Protagoras. Translated with Notes by Stanley Lombardo and Karen Bell. Indianapolis: Hackett.

Gagarin, Michael. 1969. The Purpose of Plato's Protagoras. Transactions and Proceedings of the American Philological Association 100: 133-164.

Garver, Eugene. 2004. Can Virtue be Bought? Philosophy and Rhetoric 37(4): 353-382.

Gonzalez, Francisco. 2000. Giving Thought to the Good Together: Virtue in Plato's Protagoras. In Retracing the Platonic Text, ed. John Sallis and John Russon, 113-154. Evanston: Northwestern University Press.

Griswold Jr., Charles. 1986. Self-Knowledge in Plato's Phaedrus. New Haven: Yale University Press.

Griswold Jr., Charles. 1999. Relying on Your Own Voice: An Unsettled Rivalry of Moral Ideals in Plato's Protagoras. Review of Metaphysics 53(4): 283-307.

Grube, G.M.A. 1933. The Structural Unity of the Protagoras. The Classical Quarterly 3-4(27): 203-207.

Grube, G.M.A. 1975. Plato: The Trial and Death of Socrates. Indianapolis: Hackett Publishing.

Hackforth, R. 1928. Hedonism in Plato's Protagoras. The Classical Quarterly 1(22): 39-42.

Heath, Malcolm. 1989. The Unity of Plato's Phaedrus. Oxford Studies in Ancient Philosophy 7 : $151-201$. 
Hemmenway, Scott. 1996. Sophistry Exposed: Socrates on the Unity of Virtue in the Protagoras. Ancient Philosophy 16: 1-23.

Irwin, Terrance. 1977. Plato's Moral Theory: The Early and Middle Dialogues. Oxford: Oxford University Press.

Jowett, Benjamin. 1953. The Dialogues of Plato. New York: Oxford University Press.

Klosko, George. 1980. On the Analysis of 'Protagoras' 351B-360E'. Phoenix 34(4): 307-322.

Kraut, Richard. 1984. Socrates. Ancient Philosophy 2(4): 246-249.

Lamb, W.R.M. 1967. Plato in Twelve Volumes. Cambridge, MA/London: Harvard University Press/William Heinemann Ltd.

Lavery, Jonathan. 2007. Plato's Protagoras and the Frontier of Genre Research: A Reconnaissance Report from the Field. Poetics Today 28(2): 191-246.

Long, Christopher. 2005. Character and Consensus in Plato's Protagoras. The Cambridge Classical Journal 51: 1-20.

Mackenzie, M.M. 1982. Paradox in Plato's 'Phaedrus'. Proceeding of the Cambridge Philological Society 208(New Series 28): 64-76.

McCoy, Marina. 1999. Socrates on Simonides: The Use of Poetry in Socratic and Platonic Rhetoric. Philosophy and Rhetoric 31: 349-367.

McCoy, Marina. 2008. Plato on the Rhetoric of Philosophers and Sophists. Cambridge: Cambridge University Press.

Moss, Jessica. 2013. Hedonism and the Divided Soul in Plato's Protagoras. Penultimate draft. Final article in Archiv fur Geschichte der Philosophie. http:/www.nyu.edu/gsas/dept/philo/ faculty/moss/HedonismDividedSoulProtagoras.pdf. Accessed 13 May 2016.

Murray, James. 1988. Disputation, Deception, and Dialectic: Plato on the True Rhetoric (Phaedrus 261-166). Philosophy and Rhetoric 21(4): 279-289.

Nehamas, Alexander. 1990. Eristic, Antilogic, Sophistic, Dialectic: Plato's Demarcation of Philosophy from Sophistry. History of Philosophy Quarterly 7(1): 3-16.

Notomi, Noburu. 2004. Socratic Dialogue and Platonic Dialectic: How the Soul Knows in the Republic. Plato 4. http://gramata.univ-paris1.fr/Plato. Accessed 13 May 2016.

Notomi, Noburu. 2013. A Protagonist of the Sophistic Movement? Protagoras in Historiography. In Protagoras of Abdera: The Man, His Measure, ed. Johannes M. van Ophuijsen, Marlein van Raalte, and Peter Stork, 11-36. Leiden: Brill.

O'Brien, Denis. 2003. Socrates and Protagoras on Virtue. Oxford Studies in Ancient Philosophy 34: 59-131.

Pappas, Nickolas. 1989. Socrates' charitable treatment of poetry. Philosophy and Literature 13(2): 248-261.

Penner, Terence. 1973. The Unity of Virtue. Philosophical Review 82(1): 35-68.

Pettersson, Olof. 2013. A Multiform Desire. Uppsala: Department of Philosophy, Uppsala University.

Politis, Vasilis. 2012. What do the Arguments in the Protagoras Amount to? Phronesis 3(57): 209-239.

Prior, William. 1998. Plato and the 'Socratic Fallacy'. Phronesis 43(2): 97-113.

Rademaker, Adriaan. 2013. The Most Correct Account: Protagoras on Language. In Protagoras of Abdera: The Man, His Measure, ed. Johannes M. van Ophuijsen, Marlein van Raalte, and Peter Stork, 87-111. Leiden: Brill.

Robinson, Richard. 1953. Plato's Earlier Dialectic. Oxford: Oxford University Press.

Rowe, C.J. 1986. The Argument and Structure of Plato's Phaedrus. Proceeding of the Cambridge Philological Society 212(New Series 32): 106-205.

Russel, Daniel. 2000. Protagoras and Socrates on Courage and Pleasure. Ancient Philosophy 20(2): 311-338.

Sauppe, Hermann. 1889. Commentaries, in Plato. In Protagoras. Boston: Ginn.

Schofield, Malcolm. 1992. Socrates Versus Protagoras. In Socratic Questions, ed. Grover and Stokes, 122-136. London: Routledge. 
Smith, William. 1873. A Dictionary of Greek and Roman Biography and Mythology. London, John Murray: printed by Spottiswoode and Co., New-Street Square and Parliament Street.

Stenzel, Julius. 1973. Plato's Method of Dialectic (trans. Allan, D.J.). New York: Arno Press.

Stokes, Michael. 1986. Plato's Socratic Conversations: Drama and Dialectics in Three Dialogues. Baltimore: John Hopkins University Press.

Taylor, C.C.W. 1976. Protagoras. Oxford: Clarendon.

Trivigno, Franco. 2013. Childish Nonsense? The Value of Interpretation in Plato's Protagoras. Journal of the History of Philosophy 51(4): 509-543.

Vernant, Jean-Pierre, and Marcel Detienne. 1974. Les ruses de l'intelligence la metis des grecs. Paris: Flammarion.

Vlastos, Gregory. 1956. Introduction. In Protagoras. Trans. B. Jowett, revised by M. Ostwald. Indianapolis: The Library of Liberals, Bobbs-Merrill Co.

Vlastos, Gregory. 1972. The Unity of the Virtues in the Protagoras. Review of Metaphysics 25(3): $415-458$.

W.K.C. Guthrie. 1961. Protagoras, Translation and Comments, New York: Pantheon Books.

Wolfsdorf, David. 2004. Socrates' Avowals of Knowledge. Phronesis 2(49): 75-142.

Woodbury, Leonard. 1953. Simonides on Apetń. Transactions of the American Philological Association 84: 135-163.

Woodruff, Paul. 1976. Socrates on the Parts of Virtue. In New Essays on Plato and the PreSocratics: Canadian Journal of Philosophy (supp. 2), eds. R. Shiner and J. King-Farlow, 107-10.

Woodruff, Paul. 2013. Eubolia as the Skill Protagoras Taught. In Protagoras of Abdera: The Man, His Measure, ed. Johannes M. van Ophuijsen, Marlein van Raalte, and Peter Stork, 175-193. Leiden: Brill.

Woolf, Raphael. 1999. The Written Words in Plato's Protagoras. Ancient Philosophy 19(1): 21-30.

Zeyl, Donald. 1980. Socrates and Hedonism: Protagoras 351b-358d. Phronesis 25(3): 250-269. 